\title{
Occurrence of Franciscana (Pontoporia blainVillei) IN BAÍA Norte, SOUTHERN BRAzIL ${ }^{1}$
}

\author{
Paulo A. C. Flores ${ }^{2}$
}

The franciscana (Pontoporia blainvillei) occurs in coastal waters of the western South Atlantic from the State of Espírito Santo $\left(18^{\circ} 25^{\prime} \mathrm{S}, 30^{\circ} 42^{\prime} \mathrm{W}\right)$, Brazil, to Península Valdés $\left(42^{\circ} 35^{\prime} \mathrm{S}, 64^{\circ} 48^{\prime} \mathrm{W}\right)$, Argentina (Crespo, 2002; Bordino et al., 2002). Most information on the species comes from stranding and bycatch records (see reviews by Crespo, 2002, and by Bordino et al., 2002). Although sightings have been reported for Argentina (see review in Bordino et al., 2002) and Brazil (Bordino et al., 2002; Di Beneditto et al., 1998; Flores et al., 20003; Moreno et al., 2003; Santos et al., 2007), it appears that in only three areas it is possible to conduct systematic observation of franciscanas: Bahia Anegada $\left(40^{\circ} 30^{\prime} \mathrm{S}, 6^{\circ} 10^{\prime} \mathrm{W}\right)$, Argentina (Bordino et al., 1999; Bordino, 2002), Baía de Babitonga $\left(27^{\circ} 32^{\prime} \mathrm{S}, 48^{\circ} 20^{\prime} \mathrm{W}\right)$, southern Brazil (Cremer and Simões-Lopes, 2005) and Baía das Laranjeiras $\left(25^{\circ} 25^{\prime} \mathrm{S}, 48^{\circ} 21^{\prime} \mathrm{W}\right)$, also in southern Brazil (Santos et al., 2009). Herein, information is presented on distribution, occurrence, group size and composition of franciscanas in Baía Norte, Santa Catarina State, Brazil, based on six sightings made between 1996 and 2003 during ongoing research on the Guiana dolphin (Sotalia guianensis) and bottlenose dolphin (Tursiops truncatus) (Flores, 1999; Flores and Bazzalo, 2004; Flores and Fontoura, 2006). These sightings add to two previous ones reported for Baía Norte by Flores et al. (2000) ${ }^{3}$.

Baía Norte and surrounding waters (27 $23^{\prime}-27^{\circ} 35^{\prime} S$, $\left.48^{\circ} 33^{\prime}-48^{\circ} 30^{\prime} \mathrm{W}\right)$ is located on the southern Brazilian coast (Figure 1). This is a shallow bay with bottom depths usually less than $12 \mathrm{~m}$ except in the North Channel, where the bottom depth is approximately $14 \mathrm{~m}$, and in the strait connecting to South Bay, where bottom depth is greater than $25 \mathrm{~m}$. Strandings and by-catches of franciscanas have been recorded in Baía Norte as well as along the adjacent open shore to the Atlantic Ocean (Simões-Lopes and Ximenez, 1993; Cherem et al., 2004).

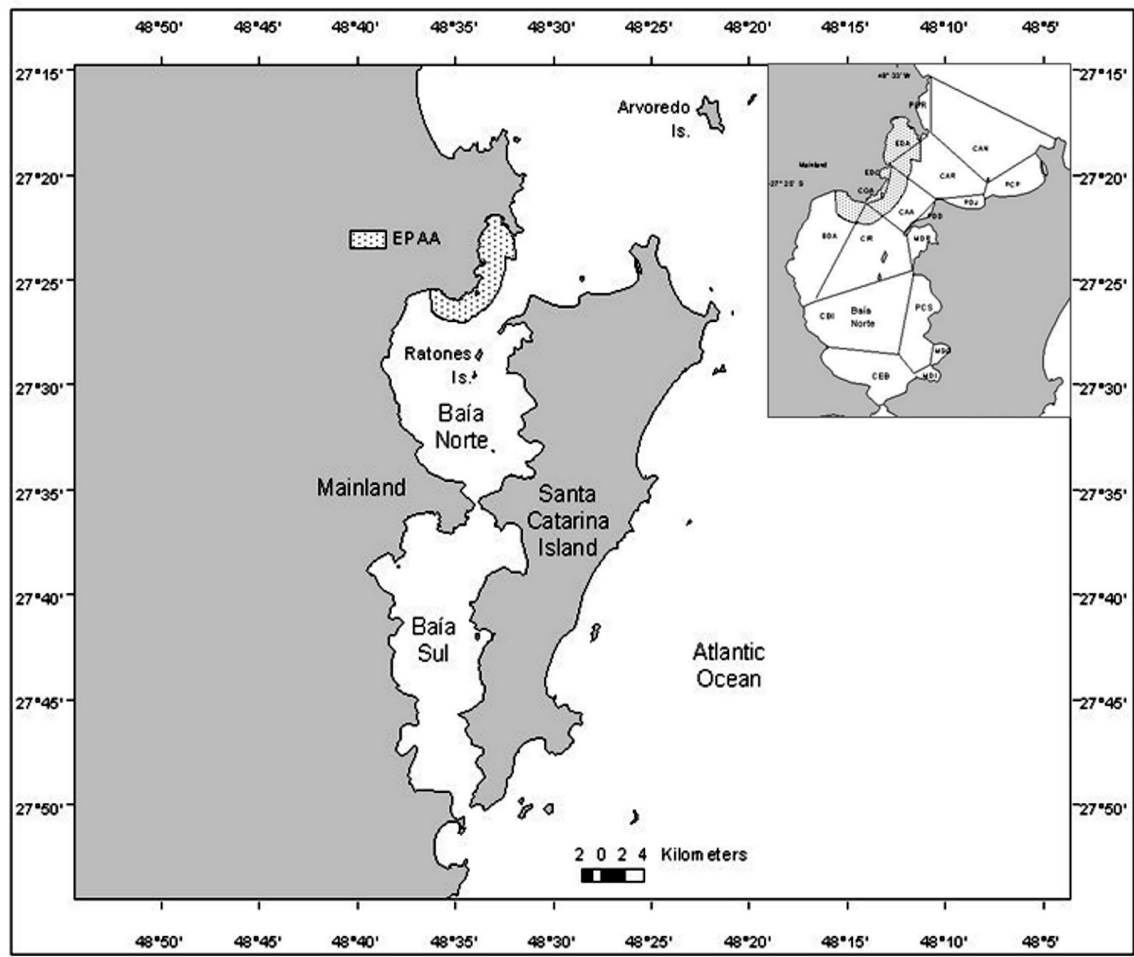

Figure 1. Map of the Baía Norte study area, southern Brazil. EPAA: Environmental Protection Area of Anhatomirim.

\footnotetext{
${ }^{1}$ Received on 22 July 2008. Accepted on 12 May 2010. Managed by Nélio Barros / Diane Gendron.

${ }^{2}$ Centro Mamíferos Aquáticos - CMA, Centro Nacional de Pesquisa \& Conservação de Mamíferos Aquáticos, ICMBio, MMA, CMA SC, Rod. Maurício Sirotsky Sobrinho, s/n, km02, Jurerê, Florianópolis, SC, 88053-700 Brasil. E-mails: paulo.flores@icmbio.gov.br, flores.p@terra.com.br.

${ }^{3}$ Flores, P.A.C., Sousa-Lima, R. S. and Siqueira, G. S. (2000) Avistagens de franciscana (Pontoporia blainvillei) na Baía Norte, Santa Catarina, Sul do Brasil. Pages 71-74 in Report of the Third Workshop for Coordinated Research and Conservation of the Franciscana Dolphin (Pontoporia blainvillei) in the Southwestern Atlantic, UNEP/CMS publication 112pp. [Available from UNEP/CMS Secretariat,
} 
Methods for data collection included boat surveys, behavioral sampling observations and measurement of environmental variables, as part of a long-term study on Guiana and bottlenose dolphins as noted above. When a group of dolphins was found, time and location were collected with a hand-held GPS. Group size and composition were recorded every 5 minutes following focal group sampling (sensu Altmann, 1974, and Mann, 1999). Group composition was defined using two categories: adults and calves, the latter determined when small individuals were observed in echelon position with an adult. The environmental variables recorded were water temperature at $1 \mathrm{~m}$ depth using a mercury thermometer, water transparency using a Secchi disc and bottom depth with a hand-held depth sounder. Seasons were defined as: Autumn, 21 March - 20 June; Winter, 21 June - 20 September; Spring, 21 September 20 December; Summer, 21 December - 20 March.

Groups ranged from 3 to 12 individuals in size and were mostly composed of adults (Table 1 ), which is consistent with the range reported elsewhere for the species (Bordino et al., 1999; Bordino, 2002; Secchi et al., 2001;
Crespo et al., 1998; Di Beneditto et al., 2001; Moreno et al., 2003; Santos et al., 2009). Franciscanas occurred in waters ranging in temperature from 16.5 to $23^{\circ} \mathrm{C}$, depth from 4 to $8.6 \mathrm{~m}$ and turbidity from 61 to $150 \mathrm{~cm}$ (Table 1 ). These environmental conditions are similar to those typically reported for Guiana and bottlenose dolphins reported in this area (Flores, 1999; Flores and Bazzalo, 2004; Flores and Fontoura, 2006). One half of all franciscana sightings occurred in Winter and none were recorded in Autumn (Table 1). Four franciscana sightings occurred within the local distribution range of the Guiana dolphin as reported by Flores (1999), Flores and Bazzalo (2004), and Flores and Fontoura (2006), while two sightings were recorded inside the local range of the bottlenose dolphin (Flores and Fontoura, 2006). However, no dolphins of these species were seen close to the franciscanas at the time of the sightings.

Five of the six sightings $(83 \%)$ occurred inside the Environmental Protection Area of Anhatomirim (EPAA), a multiple-use, federal marine protected area created in 1992 mainly to ensure protection of the wild resident population of Guiana dolphins (Figure 2).

Table 1. Summary information on franciscana groups sighted in Baía Norte, Santa Catarina State, Brazil, $1996-2003$.

\begin{tabular}{cccccccc}
\hline \hline SIGHTING \# & DATE & SEASON & GROUP SIZE & $\begin{array}{c}\text { GROUP } \\
\text { COMPOSITION }\end{array}$ & $\begin{array}{c}\text { WATER TEMPERATURE } \\
\left({ }^{\circ} \mathrm{C}\right)\end{array}$ & $\begin{array}{c}\text { SECCHI DISK } \\
(\mathrm{cm})\end{array}$ & $\begin{array}{c}\text { DEPTH } \\
(\mathrm{m})\end{array}$ \\
\hline \hline 1 & 14-Feb-96 & Summer & 10 & Adults + Calf & - & - \\
2 & 12-Jul-97 & Winter & $6-8$ & Adults & - & - \\
3 & $28-J u n-02$ & Winter & $10-12$ & Adults & 16.4 & 5.7 to 8.6 \\
4 & 09-Jul-03 & Winter & 7 & Adults + Calf? & 19 & 150 & 110 \\
5 & 21-Nov-03 & Spring & $6-7$ & Adults & 22 & 6.7 \\
6 & 25-Nov-03 & Spring & $3-4$ & Adults & 23 & 6.3 \\
\hline \hline
\end{tabular}

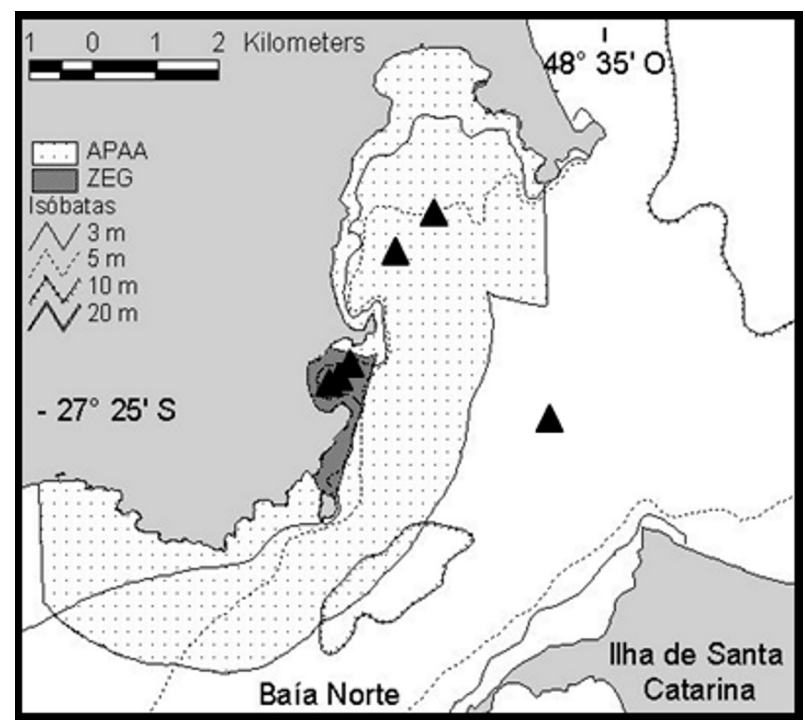

Figure 2. Sighting locations of franciscanas $(\boldsymbol{\Delta})$ with limits of the Environmental Protection Area of Anhatomirim (APAA, stippled area) and the Dolphin Exclusive Zone (ZEG, dark gray area). 
Therefore, it appears that protection measures aimed at Guiana dolphins, such as closure of areas to tourism boats as already applied in a Dolphin Exclusive Zone (ZEG, Figure 2) and fishery restricted zones and/or restrictions of fishing net types, may help protect franciscanas and bottlenose dolphins in this area as well. The occurrence of a cetacean species vulnerable to extinction (Ministério do Meio Ambiente, 20034; IUCN, $2010^{5}$ ) inside the EPAA reinforces its importance in terms of further investments in its protection.

\section{Acknowledgements}

The franciscana records were made during the dolphin research and conservation program funded by Fundação $O$ Boticário de Proteção à Natureza, Whale and Dolphin Conservation Society, Cetacean Society International, Society for Marine Mammalogy, IDEA WILD, International Wildlife Coalition - Brazil, Humane Society of the United States, Ibama and Earthwatch Institute. The author received a doctoral scholarship from Conselho Nacional de Desenvolvimento Científico e Tecnológico during 1999-2003 (CNPq Proc. 146609/ 1999-9). Pablo Bordino and Dagmar Fertl kindly commented on an early version of the manuscript. The article was also improved by comments from peer reviews by Marcos C.O. Santos and Bob Brownell.

\section{References}

Altmann, J. (1974) Observational study of behavior: sampling methods. Behaviour 49: 227-267.

Bordino, P. (2002) Movement pattern of franciscana dolphins (Pontoporia blainivillei) in Bahia Anegada, Argentina. Latin American Journal of Aquatic Mammals 1(1): 71-76.

Bordino, P., Thompson, G. AND IÑIGUEZ, M. (1999) Ecology and behaviour of the franciscana dolphin Pontoporia blainvillei in Bahía Anegada, Argentina. Journal of Cetacean Research and Management 1(2): 213-222.

Bordino, P., Siciliano, S., Bastida, R. and Cremer, M. (2002) Report of the working group on distribution and behavior. Latin American Journal of Aquatic Mammals 1(1): 21-23.

Cherem, J.J., Simões-Lopes, P.C., Althoff, S. And Graipel, M.E. (2004) Lista dos mamíferos do estado de Santa Catarina, sul do Brasil. Mastozoología Neotropical 11(2): 151-184.
CREMER, M.J. AND Simões-Lopes, P.C. (2005) The occurrence of Pontoporia blainvillei (Gervais \& d'Orbigny) (Cetacea, Pontoporiidae) in an estuarine area in southern Brazil. Revista Brasileira de Zoologia 22(3): 717-723.

CRespo, E.A. (2002) Franciscana, Pontoporia blainvillei. Pages 482485 in Perrin, W.F., WÜrsig, B. ANd Thewissen, J.G.M. (Eds) Encyclopedia of Marine Mammals. Academic Press, San Diego, USA.

Di BeneditTo, A.P.M., Ramos, R.M.A. AND Lima, N.R.W. (2001) Sightings of Pontoporia blainvillei (Gervais \& D'Orbigny, 1844) and Sotalia fluviatilis (Gervais, 1853) (Cetacea) in Southeastern Brazil. Brazilian Archives of Biology and Technology 44(3): 291-296.

Flores, P.A.C. (1999) Preliminary results of a photoidentification study of the marine tucuxi Sotalia fluviatilis in southern Brazil. Marine Mammal Science 15(3): 840-847.

Flores, P.A.C. And Bazzalo, M. (2004) Home ranges and movements patterns of the marine tucuxi Sotalia fluviatilis in Baía Norte, southern Brazil. Latin American Journal of Aquatic Mammals 3(1): 37-52.

Flores, P.A.C. AND FonTOURA, N.F. (2006) Ecology of marine tucuxi, Sotalia guianensis, and bottlenose dolphin, Tursiops truncatus, in Baía Norte, Santa Catarina State, southern Brazil. Latin American Journal of Aquatic Mammals 5(2): 105-115.

MANN, J. (1999) Behavioral sampling methods for cetaceans: a review and critique. Marine Mammal Science 15(1): 102-122.

Moreno, I.B., Martins, C.C.A., Andriolo, A. And Engel, M.H. (2003) Sightings of franciscana dolphins (Pontoporia blainvillei) off Espírito Santo, Brazil. Latin American Journal of Aquatic Mammals 2(2): 131-132.

Santos, M.C. de O., Pacífico, E. dos S. and Gonçalves, M.F. (2007) Unusual record of franciscana dolphins (Pontoporia blainvillei) in inner waters of the Cananéia estuary, southeastern Brazil. Latin American Journal of Aquatic Mammals 6(1): 117-119.

Santos, M.C. De O., Oshima, J.E.F. And Da Silva, E. (2009) Sightings of franciscana dolphins (Pontoporia blainvillei): the discovery of a population in the Paranaguá Estuarine Complex. Brazilian Journal of Oceanography 57(1): 57-63.

Secchi, E.R., Ott, P.O., Crespo, E.A., Kinas, P.G., Pedraza, S.N ANd Bordino, P. (2001). A first estimate of franciscana (Pontoporia blainvillei) abundance off southern Brazil. Journal of Cetacean Research and Manangement 3(1): 95-100.

Simões-Lopes, P.C. AND XIMENEZ, A. (1993) Annotated list of the cetaceans of Santa Catarina coastal waters, southern Brazil. Biotemas 6(1): 67-92.

\footnotetext{
${ }^{4}$ Ministério de Meio Ambiente (2003) Lista Oficial das Espécies da Fauna Brasileira Ameaçadas de Extinção. Instrução Normativa No. 3, de 27 de maio de 2003. Diário Oficial da República Federal do Brasil, Brasilia, DF. Seção 1, 101:88-97.

${ }^{5}$ IUCN (2010) IUCN Red List of Threatened Species. Version 2010.1. Available online at <www.iucnredlist.org>. Consulted on 12 May 2010.
} 